\title{
Clinical and molecular diagnosis of Chlamydophila in captive parrots in Pará State, Brazil
}

\section{Estudo clínico e diagnóstico molecular de Chlamydophila sp. em psitaciformes mantidos em cativeiro no Estado do Pará, Brasil}

\author{
Simone Aparecida Almeida Araujo'; Washington Luiz Assunção Pereira ${ }^{2 *}$; \\ Sandro Patroca da Silva ${ }^{3}$; Jedson Ferreira Cardoso ${ }^{4}$; Ednaldo da Silva Filho²; \\ Marcella Katheryne Marques Bernal ${ }^{5}$; Fernanda Figueiredo Mendes²; \\ Márcio Roberto Teixeira Nunes ${ }^{3}$
}

\begin{abstract}
Parrots (Order Psittaciformes) are globally distributed birds that, together with members of the Columbiformes, represent the most susceptible animals, in regards to infection by Chlamydophila psittaci, which is an obligate, zoonotic, intracellular bacterium that causes chlamydiosis in domestic and wild birds and psittacosis in humans. The aim of the present study was to assess the occurrence of C. psittaci in Brazilian psittacids kept in conservation breeding sites in Pará State, Brazil. Cloacal and oropharynx swab samples were collected from 201 psittacids that were distributed among four breeding sites: Metropolitan Area of Belém ( $\mathrm{C} 1$ and $\mathrm{C} 2)$, Northeastern Pará (C3), and Low Amazon (C4). The samples were screened for C. psittaci using semi-nested PCR, and the resulting incidence data were analyzed using proportion and chi-square tests. Chlamydophila infection was confirmed for all the breeding sites, with an overall prevalence of $31.84 \%$, and no species-specific predisposition was observed. Furthermore, $13.93 \%$ of the sampled birds eliminated the infectious agent by the cloaca, whereas $11.44 \%$ eliminated the agent by the oropharynx, and $6.47 \%$ eliminated the agent by both routes. Moreover, there was a significant difference between the incidence of Chlamydophila infection of breeding sites $\mathrm{C} 2$ and $\mathrm{C} 3(\mathrm{p}=0.029)$, which yielded the smallest and largest number of diagnosed cases, respectively. In the present study, most of the birds (27.86\%) were considered unapparent carriers of Chlamydophila infection, and only $3.98 \%$ of the birds yielded both a positive diagnosis and clinical signs of chlamydiosis.
\end{abstract}

Key words: Captivity. Chlamydiosis. Psittacids. Semi-nested PCR.

\section{Resumo}

Psitacídeos são aves distribuídas em todo o mundo e, juntamente com Columbiformes, representam os animais mais suscetíveis a uma infecção causada por Chlamydophila psittaci, uma bactéria intracelular, obrigatória, zoonótica que causa clamídia em aves domésticas e selvagens e psitacose em humanos. O objetivo deste estudo foi avaliar a ocorrência de C. psittaci em diferentes espécies de psitacídeos

1 Profa , Instituto Federal de Educação, Ciência e Tecnologia do Pará, IFPA, Marabá, PA, Brasil. E-mail: simonearaujo.vet@gmail.com

2 Profs., Universidade Federal Rural da Amazônia, UFRA, Belém, PA, Brasil. E-mail: wkarton@terra.com.br; silva.filho@ufra. edu.br; nanda_vt@yahoo.com.br

3 Pesquisadores, Instituto Evandro Chagas, IEC, Ananindeua, PA, Brasil. E-mail: spatroca@gmail.com; marciones@iec.pa.gov.br

4 Discente, Instituto Evandro Chagas, IEC, Ananindeua, PA, Brasil. E-mail: jedsoncardoso@hotmail.com

5 Discente, UFRA, Belém, PA, Brasil. E-mail: mkbernalfh@gmail.com

* Author for correspondence 
da fauna brasileira mantidos em criadouros conservacionistas no Estado do Pará, Brasil. Amostras de swabs de cloaca e orofaringe de 201 psitacídeos distribuídos em quatro criadouros nas mesorregiões Metropolitana de Belém (C1 e C2), Nordeste do Pará (C3) e Baixo Amazonas (C4) foram utilizados. As amostras foram submetidas ao teste molecular de semi-nested PCR. As análises estatísticas foram realizadas de acordo com o teste de proposição por $\mathrm{R}$ e teste do qui-quadrado $(\mathrm{p}<0,05)$. A presença de Chlamydophila sp. foi confirmada em todos os criadouros, com uma prevalência de 31,84\% de aves infectadas, com predisposição não específica da espécie encontrada para a infecção entre as aves amostradas. Os resultados da semi-nested PCR mostraram que 13,93\% das aves eliminaram o agente infeccioso pela cloaca, $11,44 \%$ pela orofaringe e $6,47 \%$ por ambas. Além disso, quando aplicado em cada local, este teste mostrou uma diferença estatisticamente significativa entre os criadouros $\mathrm{C} 2 \mathrm{e}$ C3 $(p=0,029)$, que apresentou o menor e maior número de casos diagnosticados, respectivamente. A maioria dos animais, ou $27,86 \%$, foi considerada como portadora inaparente da infecção e apenas $3,98 \%$ das aves com diagnóstico positivo apresentaram algum sinal clínico sugestivo da doença.

Palavras-chave: Cativeiro. Clamídia. Psitacídeos. Semi-nested PCR.

\section{Introduction}

Brazil harbors the greatest diversity of parrots (Order Psittaciformes) in the world. These birds are distributed throughout tropical areas of the globe and are even found in cold regions, such as Patagonia. South America is home to $\sim 100$ species of the Psittacidae, 72 of which are found in Brazil, and more species from this group are listed in the Brazilian Fauna Threatened with Extinction than any other group of animals (MACHADO et al., 2008).

The Psittacidae includes macaws, parrots, cockatoos, aratingas, caiques, eclectus, forpus, lovebirds, cockatiel, rosellas, and many others, each of which possesses exuberant plumage, welldeveloped brains, and their own distinct anatomical characteristics (PERECIN et al., 2011).

The health of these animals can be compromised by a variety of biological agents, including viruses, fungi, and, especially, bacteria. Among the main infectious diseases that affect psittacids, chlamydiosis is the most important. The etiologic agent of chlamydiosis, namely Chlamydophila pisittaci, is an obligate, Gram-negative, zoonotic, intracellular coccobacillus that is capable of causing clinically evident systemic disease in many mammals, reptiles, amphibians, and birds (REVOLLEDO; FERREIRA, 2009).
However, in birds, chlamydiosis is not associated with any specific clinical signs. Therefore, clinical diagnosis is difficult, and infected animals may persist as asymptomatic carriers for long periods, thereby representing an important source of infection for humans and other birds. The development of the clinical form of this disease depends on a variety of factors, such as the species affected, serotype virulence, age, and host immunological status (HARKINEZHAD et al., 2009; PROENÇA et al., 2011).

Furthermore, wild Chlamydophila-infected birds may be important in the dissemination of chlamydiosis since agent elimination is stimulated by stress conditions, such as handling, transport, and inadequate quantity or quality of food received. Infection may also be unapparent, and agent excretion can occur intermittently in feces and respiratory exudate (RASO, 2007).

Polymerase chain reaction (PCR) is the main method used to diagnose Chlamydophila infection in humans, birds, and other animal species, owing to its high specificity and sensitivity (RASO, 2006). According to this author, molecular analysis of cloacal and oropharynx swab samples facilitate the diagnosis of chlamydiosis and are also widely used to assess the sanitary status of bird populations, by facilitating the diagnosis of a variety of diseases (e.g., mycoplasmosis, aspergillosis, polyomaviruses, salmonellosis, colibacillosis, and pullorosis). 
The characterization of chlamydiosis as a public health concern, owing to its high zoonotic potential and the to the paucity of data regarding its prevalence in Pará State, indicates the importance of conducting clinical and molecular studies to assess the prevalence of Chlamydophila infection in captive psittacids in the region. Accordingly, the aim of the present study was to assess the occurrence of chlamydiosis in Brazilian psittacids kept in conservation breeding sites in Pará State, Brazil.

\section{Material and Methods}

\section{Animals and collection sites}

This research was licensed by National System of Biodiversity Information - SISBIO under No.
39285 and by the Ethics Committee on Animal Use of the Federal Rural University of Amazônia (CEUA-UFRA, authorization No. 034/2014).

The present study involved 201 birds from four breeding sites. The breeding sites are authorized by the National Wildlife Management System (SisFauna) and are located in the following mesoregions: Metropolitan Area of Belém (C1 and C2), Northeastern Pará (C3), and Low Amazon (C4). All animals were adults, without distinction between males and females, and were identified as members of the Psittaciformes, including 16 species from eight genera (Table 1).

Table 1. Distribution of sampled species among four breeding sites in Pará State, Brazil.

\begin{tabular}{llllllc}
\hline \multicolumn{1}{c}{ Common Name } & \multicolumn{1}{c}{ Scientific Name } & B1 & B2 & B3 & B4 & Total \\
\hline Papagaio-verdadeiro & Amazona aestiva & 01 & 02 & 16 & 00 & 19 \\
Papagaio-papa-cacau & Amazona festiva & 00 & 02 & 00 & 01 & 03 \\
Papagaio-moleiro & Amazona farinosa & 00 & 03 & 08 & 08 & 19 \\
Papagaio-campeiro & Amazona ochrocephala & 00 & 00 & 00 & 08 & 08 \\
Papagaio-do-mangue & Amazona amazônica & 21 & 09 & 09 & 37 & 76 \\
Arara-azul-grande & Anodorhynchus hyacinthinus & 00 & 02 & 00 & 03 & 05 \\
Ararinha azul & Cyanopsitta spixii & 00 & 00 & 06 & 00 & 06 \\
Ararinha-verde & Ara ambigua & 00 & 05 & 00 & 01 & 06 \\
Arara- Canindé & Ara ararauna & 01 & 02 & 00 & 01 & 04 \\
Arara-vermelha-grande & Ara chloropterus & 03 & 04 & 00 & 08 & 15 \\
Arara-vermelha-pequena & Ara macao & 03 & 01 & 00 & 06 & 10 \\
Maracanã-verdadeiro & Ara maracanã & 03 & 02 & 00 & 03 & 08 \\
Ararajuba & Guaruba guarouba & 00 & 04 & 11 & 02 & 17 \\
Macaranã-do-buriti & Orthopsittaca manilatus & 00 & 00 & 00 & 01 & 01 \\
Anacã & Deroptyus accipitrinus & 00 & 02 & 00 & 00 & 02 \\
Marianinha-de-cabeça-preta & Pionites melanocephala & 00 & 02 & 00 & 00 & 02 \\
\hline Total & & 32 & 40 & 50 & 79 & 201 \\
\hline
\end{tabular}

$\mathrm{B}=$ Breeding. 
Clinical examination and breeding site assessment

The birds were subject to individual clinical examinations, with data collected in regards to the presence of clinical signs of chlamydiosis, such as apathy, anorexia, plumage changes, conjunctivitis, and respiratory, digestive, urinary, or neurological disorders.

The management practices and sanitation conditions under which these animals were kept were also evaluated for each breeding site using an assessment form in order to identify possible environmental interferences that could favor the manifestation or dissemination of disease.

The sanitation conditions of each breeding site were graded (A, B, or C) on the basis of parameters related to the control of disease dissemination (i.e., cleanliness of enclosures and food and water troughs, stocking of breeding sites, use of personal protective equipment by staff members, and adoption of quarantine and individual enclosures). Grade A was applied to breeding sites that possessed satisfactory sanitation conditions, which provided a healthy, safe, and adequate environment for animal care. Grade B was applied to breeding sites that possessed intermediate sanitation conditions, thereby meeting some requirements but not enough to minimize the risk of disease transmission. Grade $\mathrm{C}$ was applied to breeding sites where either the criteria contained in the sanitation assessment form were not observed or where sanitation conditions were very poor.

\section{Sample collection}

The birds were restrained manually during the collection of biological samples. For each animal, a sterile swab was rubbed in the oropharyngeal region, after opening the beak, and another was introduced and slightly rubbed in the cloacal region. Samples were only collected from each animal once, and the beaks of the sampled birds were marked with nontoxic paint for identification and, subsequently, returned to their respective enclosures.

\section{Sample preservation and analysis}

The swabs were transferred to sterile Eppendorf and kept cool in a Styrofoam with ice, and, within $12 \mathrm{~h}$, were transferred to a $-20^{\circ} \mathrm{C}$ freezer at the Laboratory of Animal Pathology, Federal Rural University of Amazônia (LABOPAT/UFRA), where the samples were stored for a maximum of $30 \mathrm{~d}$. Subsequently, all samples were sent to the Laboratory of Molecular Diagnostics, Center for Technological Innovations, Evandro Chagas Institute (CIT/IEC), where they were stored in a $-80^{\circ} \mathrm{C}$ freezer until analysis using semi-nested PCR.

\section{Polymerase chain reaction (PCR)}

Total DNA was extracted from the biological samples using Chelex 100 (sodium form; SigmaAldrich St. Louis, MO, USA), and successful extraction was confirmed using agarose gel electrophoresis.

Meanwhile, PCR was performed according to Raso et al. (2006), with some adjustments, using primers that corresponded to a conserved region of the Major Outer Membrane Protein (MOMP) gene of the bacterium: A (5'-CAGGACATCTTGTCTGGCTTTAA-3') and B (5'-GCAAGGATCGCAAGATC-3') for the first reaction, producing a 260-bp amplicon, and $\mathrm{C}$ (5'-TTAGAGGTGAGTATGAAAAAACTC-3') and B (5'-GCAAGGATCGCAAGATC-3') for the second reaction, producing a 165 -bp amplicon.

Each reaction mixture contained $5 \mu \mathrm{DNA}$ template, $2.5 \mu 110 \times$ PCR Buffer, $0.5 \mu 110 \mathrm{mM}$ dNTPs, $0.75 \mu \mathrm{l} 50 \mathrm{mM} \mathrm{MgCl}, 0.5 \mu \mathrm{M}$ of each primer, $0.1 \mu$ Platinum Taq DNA polymerase (Invitrogen, USA), and enough sterile water to ensure a final volume of $25 \mu \mathrm{l}$. 
For the first reaction, the reaction mixtures were exposed to the following conditions: $94^{\circ} \mathrm{C}$ for 10 min; followed by 34 cycles at $94^{\circ} \mathrm{C}$ for $60 \mathrm{~s}, 54$ or $52^{\circ} \mathrm{C}$ for $60 \mathrm{~s}$ (first and second reaction, respectively), and $72^{\circ} \mathrm{C}$ for $60 \mathrm{~s}$; and a final extension at $72^{\circ} \mathrm{C}$ for $4 \mathrm{~min}$.

The resulting PCR products were stained using Blue Orange solution (Invitrogen) and visualized using horizontal gel electrophoresis ( $2 \%$ agarose gel) with SYBR Safe (Invitrogen) in TAE (TrisAcetate-EDTA) buffer, along with a 100-bp molecular weight marker (Invitrogen).

The Felocell CVR-C feline vaccine (Zoetis, São Paulo/SP, Brazil) was used as a positive control since, according to the manufacturer, it contains attenuated C. felis, and ultra-pure water was used as a negative control.

\section{Statistical analyses}

The association between the results obtained in the four breeding sites was analyzed by the proportional test (prop.test) in $\mathrm{R}$ version 2.1.1. for Windows. To assess species-specific susceptibility, based on infection frequency, results of the PCR assay and sampled birds were analyzed using the chi-square test $\left(\mathrm{X}^{2}\right)$ in SPSS version 19 (IBM, Inc., Chicago, Ill.,USA). The results of the clinical examinations and sanitation assessments were summarized using descriptive analysis.

\section{Results and Discussion}

The use of the semi-nested PCR to amplify the MOMP gene of Chlamydophila sp. was efficient for diagnosing chlamydiosis in the present study; the 165-bp amplicon could be easily visualized using gel electrophoresis and a transilluminator (Figure 1).

Figure 1. Amplification of a conserved Chlamydophila DNA marker amplified from cloacal and oropharynx swabs using semi-nested PCR. Fragments were visualized using a $2 \%$ agarose gel. $\mathrm{L}=100$-bp molecular weight marker; $1^{\mathrm{A}}=$ cloacal swab sample; $1^{\mathrm{B}}=$ oropharynx swab sample; * = positive sample; $\mathrm{C}+=$ positive control (Felocell feline vaccine); $\mathrm{C}-=$ negative control (ultra-pure water). $\mathrm{PCR}+=$ PCR-positive birds; PCR $-=$ PCR-negative birds.

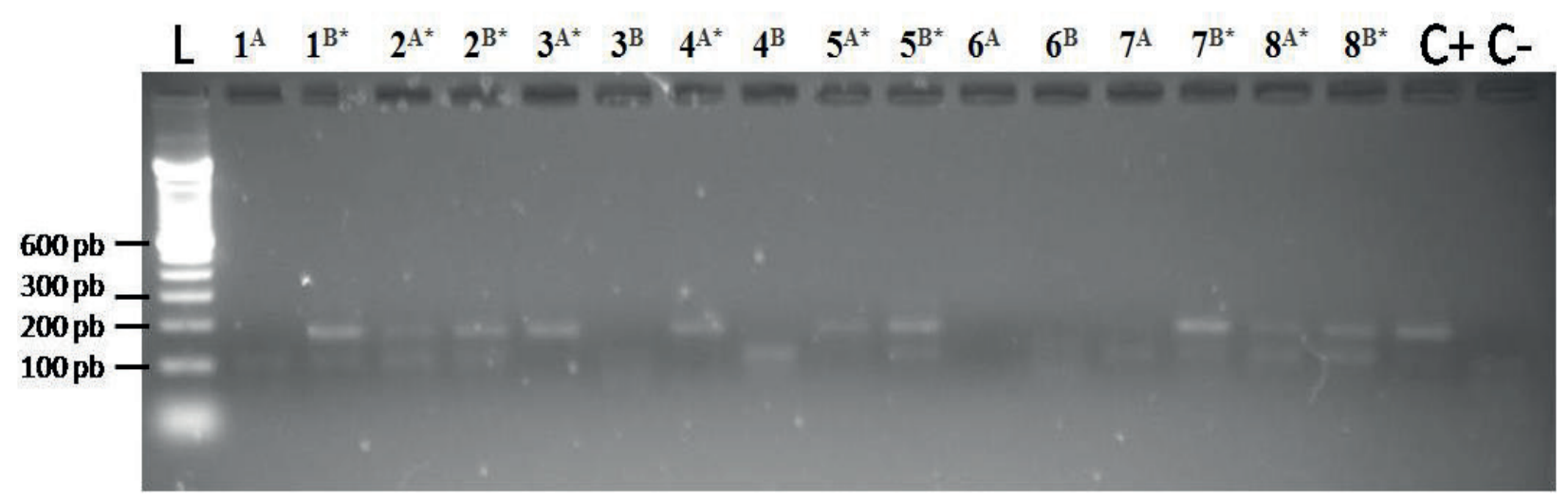

Previous studies have used semi-nested PCR to investigate the occurrence of chlamydiosis in psittacids. Raso et al. (2006), for example, reported that $23.38 \%(18 / 77)$ of psittacids were infected by Chlamydophila sp, and Vanrompay et al. (2007), Casagrande et al. (2014), and Leal et al. (2015) respectively reported that $19.2 \%(59 / 308)$, $5.09 \%(11 / 216)$, and $10.6 \%$ (33/311) of psittacids were infected by Chlamydophila sp. These results highlight the usefulness of this technique as an 
efficient alternative for diagnosing chlamydiosis and confirms the epidemiological importance of chlamydiosis in these animals.
In the present study, $31.84 \%(64 / 201)$ of the sampled animals were diagnosed with Chlamydophila infection (Table 2).

Table 2. Number of specimens analyzed according to the species and total and percentage values of the observed frequency in the species of positive psittacids in the semi-nested PCR test.

\begin{tabular}{|c|c|c|c|}
\hline Species & $\mathbf{N}^{\circ}$ specimens & Positive PCR & $\%$ \\
\hline Amazona aestiva & 19 & 07 & $36,84 \% *$ \\
\hline Amazona festiva & 03 & 02 & $66,66 \% *$ \\
\hline Amazona farinosa & 19 & 08 & $42,11 \% *$ \\
\hline Amazona ochrocephala & 08 & 03 & $37,50 \% *$ \\
\hline Amazona amazônica & 76 & 18 & $23,68 \% *$ \\
\hline Anodorhynchus hyacinthinus & 05 & 02 & $40 \% *$ \\
\hline Cyanopsitta spixii & 06 & 01 & $16,66 \% *$ \\
\hline Ara ambígua & 06 & 01 & $16,66 \% *$ \\
\hline Ara ararauna & 04 & 01 & $25 \% *$ \\
\hline Ara chloropterus & 15 & 06 & $40 \% *$ \\
\hline Ara macao & 10 & 02 & $20 \% *$ \\
\hline Ara maracanã & 08 & 03 & $37,50 \% *$ \\
\hline Guaruba guarouba & 17 & 10 & $58,82 \% *$ \\
\hline Orthopsittaca manilatus & 01 & 00 & \\
\hline Deroptyus accipitrinus & 02 & 00 & \\
\hline Pionites melanocephala & 02 & 00 & \\
\hline Total & 201 & 64 & \\
\hline
\end{tabular}

$*=$ Values with no significant statistical difference; $\mathrm{X}^{2}=13.467 ; \mathrm{p}$-value $=0.336$.

There was no significant difference $(\mathrm{p}<0.05)$ in the incidence of chlamydiosis among the 16 bird species (Table 2). Therefore, there was no evidence of susceptibility to Chlamydophila infection in the bird species included in the present study. Carvalho et al. (2017) also observed the absence of speciesspecific predisposition to infection by a variety of pathogens (e.g. Mycoplasma gallisepticum, and $M$. synoviae) in captive psittacids in Goiás State, Brazil.

However, in an epidemiological study of birds serviced at a private clinic in Brasília, Proença et al. (2011) reported that, among the animals treated $(\mathrm{n}=123)$, chlamydiosis was most prevalent in cockatiel (Nymphicus hollandicus), which accounted for $75 \%$ of suspected chlamydiosis cases and $85 \%$ of PCR-confirmed cases.

Among the birds analyzed in the present study, $13.93 \%$ (28/201) exclusively eliminated Chlamydophila by the cloacal route, and $11.44 \%$ (23/201) exclusively eliminated Chlamydophila by oropharyngeal excretion, which suggested a predominance of chronically infected animals among the assessed breeding sites (Figure 2). The occurrence of double excretion (cloaca and oropharynx) of the infectious agent was also observed in $6.47 \%(13 / 201)$ of the cases, which, according to Raso (2007), is an indication of persistent reinfection. 
According to Raso (2007), the mode of agent excretion can be used to determine the clinical stage of chlamydiosis. For example, the predominance of cloacal excretion, as observed in the present study, indicates that animals are chronically infected, whereas greater levels of bacteria in the oropharynx suggest earlier stages of infection.

Figure 2. Distribution PCR-detected cases among breeding sites and taxonomic groups. $*=$ infectious agent excretion site were statistically different in results of C2 and C3; p-value $=0.02963$.

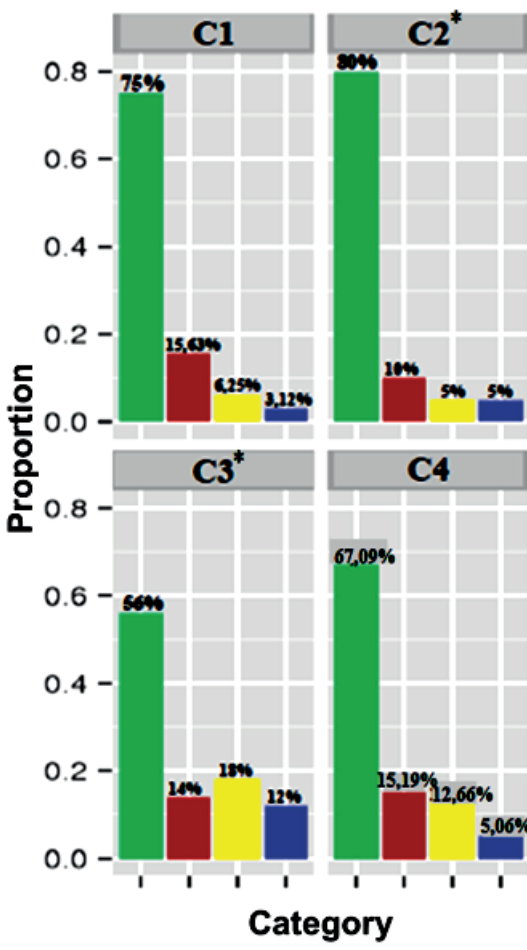

Raso et al. (2006) investigated the prevalence of Chlamydophila sp. in Anodorhynchus aestiva and A. hyacinthinus from the Pantanal of Mato Grosso State, Brazil, using semi-nested PCR and found that $26.7 \%$ of infected birds eliminated the agent by the cloacal route, compared to $8.9 \%$ by the oropharynx route, thereby confirming the importance of the chronic form of this infection. Conditions under which asymptomatic birds intermittently eliminate Chlamydophila sp. through their feces, even in the absence of clinical signs.

Similarly, in a study with 311 psittacids from commercial establishments and owners in Salvador (Bahia State, Brazil), the incidence of Chlamydophila infection was $10.6 \%$ (33/311), with

\section{Results}

\author{
Negative \\ Positive (cloaca) \\ Positive (oropharynx) \\ Positive (cloaca and oropharynx)
}

9.3\% (29/311) confirmed from cloacal samples and only $1.3 \%$ (4/308) confirmed from oropharynx samples (SANTOS et al., 2014). This indicates a pattern of chronic and persistent contamination in breeding sites, as observed in the present study.

The present study identified cases of double excretion from all the studied breeding sites. However, to the best of our knowledge, double elimination has not been reported by any other study, despite being predicted to occur (RASO, 2007).

In the present study, only $3.98 \%(8 / 201)$ of the sampled birds both presented symptoms compatible with chlamydiosis and were positively diagnosed using PCR, whereas 27.86\% (56/201) were PCR positive, but without clinical signs, thereby 
confirming the predominance of the chronic form of this infection among the studied birds (Table 3 ).

Ono (2009) investigated the prevalence of chlamydiosis in $A$. ararauna and $A$. aestiva specimens from the Wild Animals Triage Centers (CETAS) in Mato Grosso do Sul State, Brazil, and identified infection in 55.56 and $35.42 \%$ of the birds, respectively, based on a variety of signs, including whitish diarrhea, apathy, anorexia, changes in feathering (with feather loss), and atrophy of pectoral muscles, especially in A. ararauna. According to Oglesbee (1998), in chronic forms of chlamydiosis, muscle emaciation and changes in feathering may be the only clinical signs observed.

Table 3. Relationship between the presence of clinical signs suggestive of chlamydiosis and results obtained in the semi-nested PCR.

\begin{tabular}{ccccccc}
\hline Clinical evaluation/ PCR results & B1 & B2 & B3 & B4 & Total & \% \\
\hline Symptomatic/ PCR+ & $(0 / 32)$ & $(0 / 40)$ & $(6 / 50)$ & $(2 / 79)$ & $(8 / 201)$ & $3,98 \%$ \\
Symptomatic / PCR- & $(2 / 32)$ & $(3 / 40)$ & $(3 / 50)$ & $(0 / 79)$ & $(8 / 201)$ & $3,98 \%$ \\
Asymptomatic/ PCR+ & $(8 / 32)$ & $(8 / 40)$ & $(14 / 50)$ & $(26 / 79)$ & $(56 / 201)$ & $27,86 \%$ \\
Asymptomatic/ PCR- & $(22 / 32)$ & $(29 / 40)$ & $(26 / 50)$ & $(52 / 79)$ & $(129 / 201)$ & $64,18 \%$ \\
\hline
\end{tabular}

$\mathrm{PCR}+=$ positive animals in the PCR test; PCR $-=$ Negative animals in the PCR test.

$\mathrm{B}=$ Breeding.

Even though respiratory and ocular changes are the most frequently described clinical signs in infected birds (RASO et al., 2004; VAN LOOCK et al., 2005), these signs were not observed in the chlamydiosis-diagnosed birds in the present study. Only $7.96 \%(16 / 201)$ of the examined species presented clinical signs related to the disease, the only signs observed in PCR-confirmed cases were changes in beak (keratinization disorders), mutilation (absence of limb), and changes in plumage.

Asymptomatic carriers of Chlamydophila sp. were also reported by Hidasi et al. (2013), who reported that PCR analysis diagnosed infection in $3.66 \%(11 / 300)$ of specimens, whereas compatible clinical signs were only observed in two birds. Meanwhile, Braz et al. (2014) confirmed Chlamydophila infection in $4.21 \%(17 / 403)$ of asymptomatic birds.

Vasconcelos et al. (2016) reported a prevalence of $34.78 \%$ positive and asymptomatic individuals, thereby emphasizing the importance of quarantine animals, as well as the importance of using personal protective equipment when contacting such animals. Indeed, such preventive measures should be adopted, even in the absence of clinical signs that are suggestive of this disease.

The confirmed existence of asymptomatic and infected specimens by several studies, including the present study, demonstrates the importance of good practice in raising these birds, in order to reduce the risks of disseminating disease. According to Harkinezhad et al. (2009), when birds are exposed to stress factors (e.g., sanitary maintenance failures, food and water deprivation, or changes to their enclosures), clinical signs may be intensified, along with rates of agent elimination, thereby increasing the risk of infection to other birds.

The identification of Chlamydophila infection in specimens from all four breeding sites confirmed the epidemiological importance of chlamydiosis. In addition, there was a significant statistical difference between the results of $\mathrm{C} 2$ and $\mathrm{C} 3$ ( $\mathrm{p}=0.02963$; Figure 2). 
During the sanitation assessment, both sites $\mathrm{C} 1$ and $\mathrm{C} 2$ received a positive evaluation, with 66.66 $(4 / 6)$ and $83.33 \%(5 / 6)$ of grade A, respectively, and, hence, yielded relatively fewer cases of chlamydiosis. On the other hand, both sites C3 and $\mathrm{C} 4$ received poor sanitation evaluations, with only $0(0 / 6)$ and $50 \%(3 / 6)$ of good evaluations, respectively, and, hence, yielded relative more cases of chlamydiosis. These results demonstrate that environmental and sanitation factors can influence the occurrence of Chlamydophila infection.

Indeed, poor sanitation management can increase the number of chlamydiosis cases. In the present study, the breeding site with the worst sanitation evaluation yielded a higher number of infected birds than breeding sites with more efficient and consolidated management.

Environmental and sanitation factors (e.g., type of breeding site, animal origin, enclosure hygiene and stocking, time on site, and procedure for the entry of new birds) also appear to influence the occurrence of Chlamydophila sp. in the psittacid populations of zoos, Wildlife Screening Centers Cetas, and commercial and conservation breeding sites in Bahia State, Brazil (LEAL et al., 2015).

Raso (2007) and Vasconcelos et al. (2013) reported that the implementation of strict cleaning and disinfection measures in breeding sites, as well as border care, quarantining, treatment of infected birds, and movement of migratory birds, are efficient measures for controlling chlamydiosis, i.e., reducing the presence and spread of Chlamydophila in the environment.

\section{Conclusions}

The infectious agent Chlamydophila sp. was detected in specimens from all the breeding sites assessed in the present study. This finding demonstrates the epidemiological importance of chlamydiosis in captive psittacids and the need for implementing adequate sanitation management in breeding sites. The prevalence of infection in asymptomatic birds indicates the potential for captive psittacids to transmit Chlamydophila sp. to other birds, as well as to humans, thereby demonstrating the importance of the disease in public health.

\section{Acknowledgements}

We thank CAPES Brazil for the scholarship to a student postgraduate Araujo, S. A. A. and the Center for Technological Innovations - Evandro Chagas Institute, Ananindeua, State of Pará, Brazil

\section{References}

BRAZ, M. A.; SILVA, D. C.; SANTIAGO, M. E. B.; GARCIA, S. D.; NAKAMURA, A. A.; MEIRELES, M. V. Detecção e classificação molecular de Chlamydophila psittaci em amostras fecais de aves assintomáticas. Arquivo Brasileiro de Medicina Veterinária e Zootecnia, Belo Horizonte, v. 66, n. 1, p. 161-167, 2014. DOI: 10.1590/S0102-09352014000100023

CARVALHO, A. M.; ANDRADE, M. A.; JAYME, V. S.; LINHARES, G. F. C. Pesquisa de Mycoplasma em aves da família Psittacidae mantidas em diferentes cativeiros no Brasil Central. Pesquisa Veterinária Brasileira, Seropédica, v. 37, n. 10, p. 1159-1164, 2017. DOI: 10.1590/S0100-736X2017001000019

CASAGRANDE, R. A.; MACHADO, V. R.; SOUZA, S. O.; WATANABE, T. T. N.; SONNE, L.; PAVARINI, S. P.; DRIEMEIER, D. Diagnóstico imuno-histoquímico e caracterização anatomopatológica de clamidiose em psitacídeos. Pesquisa Veterinária Brasileira, Seropédica, v. 34 , n. 9, p. $885-890,2014$. DOI: 10.1590/S0100736X2014000900013

HARKINEZHAD, T.; GEENS, T.; VANRONPAY, D. Chlamydophila psittaci infections in birds: a review with emphasis on zoonotic consequences. Veterinary Microbiology, Barcelona, v. 135, n. 1-2, p. 68-77, 2009. DOI: 10.1016/j.vetmic.2008.09.046

HIDASI, H. W.; HIDASI NETO, J.; MORAES, D. M. C.; LINHARES, G. F. C.; SÁ JAYME, V. de; ANDRADE, M. A. Enterobacterial detection and Escherichia coli antimicrobial resistance in parrots seized from the illegal wildlife trade. Journal of Zoo and Wildlife Medicine, Yulee, Florida, v. 44, n. 1, p. 1-7, 2013. DOI: $10.1638 / 1042-7260-44.1 .1$ 
LEAL, D. C.; NEGRÃO, V. B.; SANTOS, F.; RASO, T. F.; BARROUIN-MELO, S. M.; FRANKE, C. R. Ocorrência de Chlamydophila psittaci em pombos (Columba livia) na cidade de Salvador, Bahia. Arquivo Brasileiro de Medicina Veterinária e Zootecnia, Belo Horizonte, v. 67, n. 3, p. 771-776, 2015. DOI: 10.1590/1678-4162-7919.

MACHADO, A. M. B.; DRUMMOND, G. M.; PAGLIA, A. P. Livro vermelho da fauna brasileira ameaçada de extinção. Brasília: MMA; Belo Horizonte: Fundação Biodiversitas, 2008. $1420 \mathrm{p}$.

OGLESBEE, B. L. Distúrbios dos animais de estimação aviários e exóticos. In: BIRCHARD, S. J.; SHERDING, R. G. Manual saunders: clínica de pequenos animais. São Paulo: Roca, 1998. p. 1397-1407.

ONO, T. M. Prevalência de Chlamydophila sp. e quadro hematológico de Ara ararauna e Amazona aestiva em centro de reabilitação de animais silvestres em Campo Grande/MS. 2009. Dissertação (Mestrado em Ciência Animal) - Universidade Federal do Mato Grosso do Sul, Campo Grande.

PERECIN, F.; CUNHA, L. L.; RIGOLETO, L.; MARTELLI, L.; BONICI, M.; GOMES, M. D.; MARTINS, T.; COSTA, T. A.; FAUSTO, T.; TAIRA, R. Manual informativo sobre posse responsável de psitacídeos. Botucatu: Universidade Estadual Paulista Júlio de Mesquita Filho, 2011. 18 p.

PROENÇA, L. M.; FAGLIARI, J. J.; RASO, T. F. Clamidophyla psittaci infection: a review with emphasis in psittacines. Ciência Rural, Santa Maria, v. 41 , n. 5 , p. $841-847,2011$. DOI: $10.1590 / \mathrm{S} 0103-$ 84782011000500017

RASO, T. F. Clamidiose. In: CUBAS, Z. S.; SILVA, J. C. R.; CATÃO-DIAS, J. L. (Org.). Tratado de animais selvagens. São Paulo: Roca, 2007. cap. 47, p. 760-767.

RASO, T. F.; GODOY, S. N.; MILANELO, L.; SOUZA, C. A. I.; MATUSHIMA, E. R.; ARAÚJO JUNIOR, J. P.; PINTO, A. A. An outbreak of chlamydiosis in captive Blue-fronted Amazon parrots (Amazona aestiva) in Brazil. Journal of Zoo and Wildlife Medicine, Yulee, Florida, v. 35, n. 1, p. 94-96, 2004. DOI: 10.1638/02-090
RASO, T. F.; SEIXAS, G. H. F.; GUEDES, N. M. R.; PINTO, A. A. Chlamydophila psittaci in free-living Bluefronted Amazon parrots (Amazona aestiva) and Hyacinth macaws (Anodorhynchus hyacinthinus) in the Pantanal of Mato Grosso do Sul, Brazil. Veterinary Microbiology, Barcelona, v. 117, p. 235-241, 2006. DOI: 10.1016/j. vetmic.2006.06.025

SANTOS, F.; LEAL, D. C.; RASO, T. F.; SOUZA, B. M. P. S.; CUNHA, R. M.; MARTINEZ, V. H. R.; BARROUIN-MELO, S. M.; FRANKE, C. R. Risk factors associated with Chlamydophila psittaci infections in psittacine birds in Salvador, Bahia, Brazil. Journal of Medical Microbiology, Reading, v. 63, p. 458-463, 2014. DOI: 10.1099/jmm.0.060632-0

VAN LOOCK, M.; VERMINNEN, K.; MESSMER, T. O.; VOLCKAERT, G.; GODDEERIS, B. M.; VANROMPAY, D. Use of a nested PCR-enzyme immunoassay with an internal control to detect Chlamydophila psittaci in turkeys. BMC Infectious Diseases, London, Inglaterra, v. 5, n. 1, p. 76-85, 2005. DOI: 10.1186/1471-2334-5-76

VANROMPAY, D.; HARKINEZHAD, T.; VAN DE WALLE, M.; BEECKMAN, D.; VAN DROOGENBROECK, C.; VERMINNEN, K.; LETEN, R.; MARTEL, A.; CAUWERTS, K. Chlamydophila psittaci transmission from pet birds to humans. Emerging Infectious Diseases, Atlanta, USA, v. 13, n. 7, p. 11081110, 2007. DOI: 10.3201/eid1307.070074

VASCONCELOS, T. B.; NOGUEIRA, D. M.; PEREIRA, V. L. A.; NASCIMENTO, E. R.; BRUNO, S. F.; Chlamydia psittaci em araras-canindé (Ara ararauna) cativas em um centro de triagem de animais silvestres no Brasil. Revista Brasileira de Ciência Veterinária, Rio de Janeiro, v. 23, n. 1-2, p. 37-41, 2016. DOI: 10.4322/ rbcv.2016.027

VASCONCELOS, T. B.; NOGUEIRA, D. M.; PEREIRA, V. L. A.; NASCIMENTO, E. R.; BRUNO, S. F. Chlamydophila psittaci em aves silvestres e exóticas: uma revisão com ênfase em saúde pública. Enciclopédia Biosfera, Centro Cientifico Conhecer, Goiânia, v. 9, n. 16, p. 2462-2477, 2013. 